\title{
Doctors in detention and the Hippocratic Oath
}

$\mathrm{E}$ very year, many newly qualified doctors recite the Hippocratic Oath upon graduating. But how many of us would actually put those words to the test if our own lives were in jeopardy? Half a world away, three physicians faced this dilemma.

During the first five months of 2009, an intense war played out in the densely populated coastline of northeastern Sri Lanka. More than 300000 civilians were trapped between battle lines. A government-imposed media blackout meant the world was largely unaware of what the United Nations called a "bloodbath."

I solemnly pledge to consecrate my life to the service of humanity. I will practice my profession with conscience and dignity. ${ }^{1}$

Doctors Thangamuthu Sathiyamoorthy, Thurairajah Varatharajah and Veerakaththi Shanmugarajah were employed by the government to work in the conflict zone. Dr. Shanmugarajah might easily have been working in a peaceful nation; several years ago, he emigrated to Canada only to return to Sri Lanka to serve the developing nation.

The physicians treated acute trauma and burns, performed surgical amputations and provided much needed first aid amidst shortages of food, medicine, clean water and supplies. Compounding the situation further was that hospitals were under artillery attack. ${ }^{2}$ Although they had the option to leave, the physicians chose to stay and serve the civilian population who needed them more than ever. At a time when journalists were barred, the physicians communicated with the outside world about the casualties they saw.

The health of my patient will be my first consideration. ${ }^{1}$

Together with the International Committee of the Red Cross, the physicians helped coordinate the evacuation of nearly 14000 patients and caregivers between mid-February and May 9, 2009. ${ }^{3}$ On May 15, they fled alongside 5000 civilians to an army crossing point. Dr. Varatharajah suffered a shrapnel injury and all three physicians were taken into custody by the Sri Lankan army.

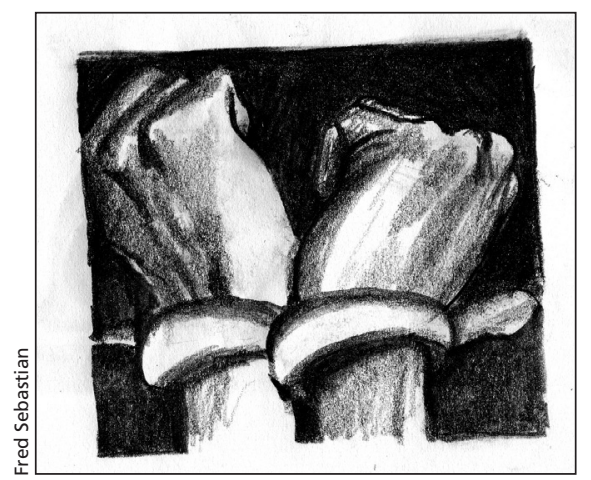

At a July 8 government media conference, the detained physicians "denied" the casualty figures they had previously given and insisted that their medical facility was not hit by artillery fire. The doctors' statements have been called into question by the United Nations and Amnesty International for contradicting independently verified facts, and have raised serious concerns about their treatment in detention. ${ }^{4}$

Amid growing international pressure, the physicians were conditionally released on bail on Aug. 24. Their movements and communication are restricted. They are due in court on Nov. 9 for allegedly providing "false information" to the international community on civilian deaths. I wonder about the justice they will receive from a judicial system that recently sentenced a journalist to 20 years imprisonment with hard labour for publishing articles critical of the government. As witnesses to the war, the doctors remain in danger as they face possibilities of harm and disappearance.

I will not permit considerations of age, disease or disability, creed, ethnic origin, gender, nationality, political affiliation, race, sexual orientation, social standing or any other factor to intervene between my duty and my patient. I make these promises solemnly, freely and upon my honour. ${ }^{1}$

What does it really mean to be a doctor? Every day I open the door to my office and hang my stethoscope around my neck. In that moment, I am no longer a daughter, a wife, a mother, a supporter of a political party, a coloured person or even a woman. I am a doctor and the health of my patient is my first consideration.

The idea that my medical colleagues face prosecution is appalling to me. During the war, the physicians worked tirelessly to save thousands of lives. They remained neutral and did not lay blame. Since the war ended, they have been compelled to deliver politically driven statements and live in fear awaiting trial.

No one is sure of the exact number of physicians who are thus imprisoned, but there are others. A June 2009 study documented the detention, torture and prosecution of 34 Kosovar Albanian physicians during the 1998-99 war. In Iran, Arash Alaei and Kamiar Alaei were imprisoned for treating patients with HIV/AIDS. The notion that medical neutrality can be distorted for political gain affects every one of us. By adhering to the duty to our patients, our lives could be altered forever.

I do not know what I would have done in these doctors' situation. But I do know that what is happening to them is wrong.

\section{Meera Selvakone MD \\ Family physician \\ Richmond Hill, Ont.}

\section{REFERENCES}

1. World Medical Association. Declaration of Geneva, 1948. Geneva (Switzerland): 2nd General Assembly of the World Medical Association; 1948.

2. Artillery attack in Sri Lanka's war zone kills 9 patients. CBC.ca [Toronto] 2009 Feb. 1. Available: www.cbc.ca/world/story/2009/02/01/srilankahospital.html (accessed 2009 Oct. 15).

3. International Committee of the Red Cross. Sri Lanka: ICRC resumes assistance to displaced people in Vavuniya camp. The Committee; Geneva (Switzerland): 2009.

4. Sri Lanka: Statements by detained doctors underline need for independent inquiry. London (UK); Amnesty International: 2009. Available: www.amnesty .org/en/library/info/ASA37/015/2009 (accessed 2009 Aug. 18)

5. Perilous medicine: The legacy of oppression and conflict on health in Kosovo. Cambridge (MA); Physicians for Human Rights: 2009. Available: http://physiciansforhumanrights.org/library/documents /reports/perilous-medicine.pdf (accessed 2009 Sept. 20).

Have you got an opinion about this article? Post your views at cmaj.ca. Potential Salon contributors are welcome to send a query to salon@cmaj.ca

All editorial matter in CMAJ represents the opinions of the authors and not necessarily those of the Canadian Medical Association. 